\title{
ANALISIS MINAT BELI TOKO KELONTONG DI KECAMATAN WONOKROMO, SURABAYA DENGAN PENDEKATAN STORE ATMOSPHERE
}

\author{
Deograsias Yoseph Y. F. \\ Program Studi Manajemen \\ Fakultas Ekonomi Universitas Katolik Darma Cendika \\ Jalan Dr. Ir. H. Soekarno 201, Surabaya \\ dyoseph279@gmail.com
}

\begin{abstract}
The grocery store industry is still facing a form of economic business that has good prospects, even in a crisis. However, in the same period many took the grocery that went bankrupt, because they were no longer able to maintain sales. There needs to be a fundamental change in the grocery store in order, but the grocery store is starting to rise from behind. As Indonesian people, are we ready to help by diverting shopping at grocery stores. By agreeing to Store Atmosphere, it is expected that willingness to buy from grocery stores will increase.
\end{abstract}

Keywords: grocery store, willingness to buy, store atmosphere.

\begin{abstract}
ABSTRAK
Industri toko kelontong hingga saat ini masih diyakini sebagai salah satu bentuk usaha ekonomi yang memiliki prospek cukup bagus, bahkan dalam kondisi krisis sekalipun. Namun demikian dalam periode yang sama banyak toko kelontong yang gulung tikar, karena tidak mampu lagi mempertahankan kuantitas penjualannya. Perlu adanya perubahan yang mendasar pada toko kelontong, agar perlahan tapi pasti toko kelontong mulai bangkit dari ketertinggalan. Sebagai masyarakat Indonesia, sudah seharusnya kita turut berpartisipasi dengan beralih belanja di toko-toko kelontong. Dengan pendekatan Store Atmosphere diharapkan minat beli dari toko kelontong meningkat.
\end{abstract}

Kata kunci: toko kelontong, minat beli, store atmosphere.

\section{PENDAHULUAN}

Industri toko kelontong hingga saat ini masih diyakini sebagai salah satu bentuk usaha ekonomi yang memiliki prospek cukup bagus, bahkan dalam kondisi krisis sekalipun. Namun demikian dalam periode yang sama banyak toko kelontong yang gulung tikar, karena tidak mampu lagi mempertahankan kuantitas penjualannya. 
Beberapa pihak yang berkompeten menyebutkan bahwa kesuksesan usaha di bidang ritel ini tidak hanya ditentukan oleh penjualan hari ini, tetapi juga ditentukan oleh kemampuan meningkatkan pertumbuhan pelanggannya secara berkelanjutan.

Bisnis toko kelontong sangat tergantung pada pelanggan, dengan kata lain bila bisnis toko kelontong dapat mampu mempertahankan pelanggan atau juga menambah pelanggan baru, secara tidak langsung bisnis toko kelontong ini akan mampu untuk bertahan dalam ketatnya persaingan dunia bisnis saat ini. Bisnis toko kelontong bukan hanya mengandalkan kelengkapan barang kebutuhan, tapi juga di dalamnya harus ada kreativitas dari pemiliknya dalam menjual barang dagangan dan kreativitas dalam mengatur suasana toko. Para pengusaha toko kelontong harus jeli melihat peluang dan berusaha semakin kreatif untuk menawarkan produknya.

Bisnis toko kelontong banyak dilakukan oleh setiap orang. Hal tersebut dikarenakan kebutuhan pokok manusia perlu segera terpenuhi dalam waktu yang sesingkat-singkatnya. Oleh sebab itu bisnis toko kelontong sangat menarik perhatian para pelaku bisnis. Selain itu bisnis toko kelontong memiliki lahan yang cukup potensial dan kreatif dalam pengelolaannya. Dari dulu hingga sekarang memang bisnis toko kelontong masih saja menjamur di Indonesia. Sayangnya, belum semua pemain lokal bernasib sama, seperti toko kelontong dan jajanan tradisional khas Indonesia. Keberadaan mereka mulai tergerus akibat persaingan usaha yang semakin ketat dan masifnya kehadiran ritel modern maupun mini market hingga supermarket menjadi penyebabnya.
Ada beberapa hal yang membuat toko kelontong sulit berkembang, antara lain: para pemilik toko kelontong tidak mendapatkan akses pada sumber barang dengan harga yang sama. Mereka membeli barang dagangan lebih mahal daripada pelaku usaha besar. Toko kelontong juga sering kesulitan mendapatkan akses permodalan untuk meningkatkan kapasitas maupun daya saing usahanya. Sekalipun ada, mereka mendapatkan pinjaman yang tidak wajar dan bunga yang besar, karena pinjaman tersebut bukan dari perbankan atau lembaga keuangan. Di samping itu, toko kelontong mayoritas kondisi dan penampilannya tidak memberikan kenyamanan bagi pembelinya.

Perlu adanya perubahan yang mendasar pada operasional dari usaha toko kelontong, agar perlahan tapi pasti toko kelontong dapat mulai bangkit dari ketertinggalan. Sebagai masyarakat Indonesia, sudah seharusnya kita turut berpartisipasi dengan beralih belanja di toko-toko kelontong, agar para pelaku usaha mikro, kecil, dan menengah (UMKM) sebagai pemilik dan pengelola toko kelontong dapat terus hidup usahanya dan dapat menyejahterakan keluarganya.

\section{TINJAUAN PUSTAKA Minat Beli}

Minat beli (willingness to buy) merupakan bagian dari komponen perilaku dalam sikap mengonsumsi. Minat beli konsumen adalah tahap di mana konsumen membentuk pilihan mereka di antara beberapa merek yang tergabung dalam perangkat pilihan, kemudian pada akhirnya melakukan suatu pembelian pada suatu altenatif yang paling disukainya atau proses yang dilalui konsumen untuk membeli suatu barang atau jasa yang 
didasari oleh bermacam pertimbangan (Suyono et al., 2012: 136).

Menurut Kotler dan Keller (2009: 15) minat beli merupakan perilaku yang muncul sebagai respon terhadap objek yang menunjukkan keinginan konsumen untuk melakukan pembelian. Durianto dan Liana (2004: 44) menyatakan minat beli merupakan sesuatu yang berhubungan dengan rencana konsumen untuk membeli produk tertentu serta berapa banyak unit produk yang dibutuhkan pada periode tertentu.

Berdasarkan uraian di atas, dapat disimpulkan bahwa minat beli merupakan pernyataan mental dari konsumen yang merefleksikan rencana pembelian sejumlah produk dengan merek tertentu. Suatu produk dikatakan telah dikonsumsi oleh konsumen apabila telah diputuskan oleh konsumen untuk dibeli. Dari beberapa pendapat di atas, dapat disimpulkan bahwa minat beli adalah kesungguhan hati untuk memiliki sesuatu pengorbanan di mana minat beli itu timbul karena konsumen merasa puas terhadap kualitas produk yang diberikan oleh perusahaan.

Perilaku seseorang sangat tergantung pada minatnya, sedangkan minat berperilaku sangat tergantung pada sikap dan norma subjektif atas perilaku. Keyakinan atas akibat perilaku sangat mempengaruhi sikap dan norma subjektifnya. Sikap individu terbentuk dari kombinasi antara keyakinan dan evaluasi tentang keyakinan yang penting bagi seorang konsumen, sedangkan norma subjektif ditentukan oleh keyakinan dan motivasi.

Konsumen di manapun dan kapanpun akan dihadapkan dengan sebuah keputusan pembelian untuk melakukan transaksi pembelian, di mana konsumen akan membandingkan atau mempertimbangkan satu barang dengan barang yang lainnya untuk mereka konsumsi. Menurut Kotler dan Keller (2009) beberapa faktor yang membentuk minat beli konsumen yaitu:

a Sikap orang lain, sejauh mana sikap orang lain mengurangi alternatif yang disukai. Seseorang akan bergantung pada dua hal yaitu, intensitas sifat negatif orang lain terhadap alternatif yang disukai konsumen dan motivasi konsumen untuk menuruti keinginan orang lain.

b. Faktor situasi yang tidak terantisipasi. Faktor ini nantinya akan dapat mengubah pendirian konsumen dalam melakukan pembelian. Hal tersebut tergantung dari pemikiran konsumen sendiri, apakah dia percaya diri dalam memutuskan akan membeli suatu barang atau tidak.

Menurut Durianto dan Liana (2004: 32) dalam melaksanakan niat pembelian, konsumen tersebut dapat membuat 5 sub keputusan pembelian sebagai berikut:

a. Keputusan merek.

b. Keputusan pemasok.

c. Keputusan kuantitas.

d. Keputusan waktu.

e. Keputusan metode pembayaran.

Minat konsumen tumbuh karena suatu motif berdasarkan atribut-atribut sesuai dengan kebutuhannya dalam menggunakan suatu produk. Berdasarkan hal tersebut, maka analisa mengenai bagaimana proses minat dari dalam diri konsumen sangat penting dilakukan. Cara terbaik untuk mempengaruhi adalah mempelajari apa yang dipikirkannya, dengan demikian akan didapatkan tidak hanya sekedar 
informasi, tetapi juga diperoleh bagaimana proses informasi itu dapat berjalan, dan bagaimana memanfaatkannya. Hal ini yang dinamakan the buying process (proses pembelian). Proses pembelian meliputi 5 hal yaitu:

\section{a. Need (kebutuhan)}

Proses pembelian berawal dari adanya kebutuhan yang tak harus dipenuhi atau kebutuhan yang muncul pada saat itu dan memotivasi untuk melakukan pembelian.

b. Recognition (pengenalan)

Kebutuhan belum cukup untuk merangsang terjadinya pembelian karena mengenali kebutuhan itu sendiri untuk dapat menetapkan sesuatu untuk memenuhinya.

c. Search (pencarian)

Merupakan bagian aktif dalam pembelian yaitu mencari jalan untuk mengisi kebutuhan tersebut.

d. Evaluation (evaluasi)

Suatu proses untuk mempelajari semua yang didapat selama proses pencarian dan mengembangkan beberapa pilihan.

e. Decision (keputusan)

Langkah terakhir dari suatu proses pembelian adalah mengambil keputusan berdasarkan informasi yang diterima.

\section{Indikator Pengukuran Minat Beli Konsumen}

Seorang konsumen tidak dengan sendirinya memiliki keputusan dalam pembelian barang atau jasa. Terlebih dahulu konsumen akan berusaha untuk mencari informasi dari orang terdekat atau orang yang benarbenar dapat dipercaya guna membantunya dalam pengambilan keputusan melakukan pembelian barang atau jasa.
Menurut Yuliadi (2006) minat beli dapat diidentifikasikan melalui indikator-indikator sebagai berikut:

a. Minat transaksional

Kecenderungan seseorang untuk membeli produk.

b. Minat refrensial

Kecenderungan seseorang untuk merekomendasi produk kepada orang lain.

c. Minat eksploratif

Minat yang menggambarkan perilaku seseorang yang selalu mencari informasi mengenai produk yang diminatinya dan mencari informasi untuk mendukung sifatsifat positif dari produk tersebut.

\section{Store Atmosphere}

Menurut Berman and Evans (1992: 462) atmosphere refers to the store's physical characteristics that are used to develop an image and to draw customers, yang berarti suasana toko merupakan karakteristik fisik toko yang digunakan untuk membangun kesan dan menarik pelanggan. Sedangkan menurut Levy and Weitz (2001: 576) suasana mengacu pada desain lingkungan melalui komunikasi visual, pencahayaan, warna, musik, dan aroma untuk merangsang pandangan pelanggan dan tanggapan emosional dan akhirnya mempengaruhi perilaku pembelian. Gilbert dalam Foster (2008: 61) menyatakan bahwa suasana toko (store atmosphere) merupakan kombinasi dari pesan secara fisik yang telah direncanakan. Store atmosphere dapat digambarkan sebagai perubahan terhadap perencanaan lingkungan pembelian yang menghasilkan efek emosional khusus yang dapat menyebabkan konsumen melakukan tindakan pembelian.

Dengan demikian store atmosphere dapat disimpulkan sebagai suatu 
kegiatan yang dilakukan dalam mendesain ruangan toko sesuai dengan barang yang dijual dan memanfaatkan fasilitas yang ada, serta dengan menentukan tema yang sesuai yang mampu membuat suasana toko menjadi menarik perhatian konsumen. Empat faktor penentu yang digunakan untuk menilai store atmosphere (suasana toko) menurut Berman and Evans (1992: 463) adalah: exterior, general interior, store layout, dan interior display.

Exterior yaitu bagian luar toko (bagian depan) yang mampu menggambarkan karakteristik toko. Design exterior yang memiliki ciri khas mampu membuat konsumen tertarik untuk masuk ke dalam toko. General interior merupakan desain bagian dalam yang bersifat umum dan diharapkan akan dapat memenuhi harapan berbagai motif konsumen memasuki toko. General interior mulai dari penataan yang dapat menarik perhatian pengunjung dan membantu mereka agar mudah mengamati, memeriksa, dan memilih barang-barang itu dan akhirnya melakukan suatu pembelian.

Store layout merupakan rencana untuk menentukan lokasi tertentu dan pengaturan dari peralatan barang dagangan di dalam toko serta fasilitas toko antara pengaturan lalu lintas toko, pengelompokan barang, dan alokasi ruang. Interior display bertujuan untuk memberikan informasi pada konsumen yang berbelanja, merupakan tambahan untuk memberikan kesan berbeda pada store atmosphere dan berfungsi sebagai alat promosi.

Suasana toko menjadi hal penting dikarenakan merupakan faktor kenyamanan yang harus diterima oleh konsumen. Semakin konsumen nyaman dengan suasana yang diberikan, maka konsumen akan terus mengingat dan tidak menutup kemungkinan konsumen tersebut akan kembali lagi. Sama seperti yang dikemukakan oleh Kotler (1973: 48) yang mengatakan identitas sebuah toko dapat dikomunikasikan kepada konsumen melalui dekorasi toko atau secara lebih luas dari atmosfernya. Meskipun sebuah atmosfer toko tidak secara langsung mengomunikasikan kualitas produk dibandingkan dengan iklan, namun atmosfer toko merupakan komunikasi secara diam-diam yang dapat menunjukkan kelas sosial dari produk-produk yang ada di dalamnya. Sehingga menurut Kotler (1973: 48) atmosfer toko dapat dijadikan sebagai alat untuk membujuk konsumen menggunakan jasa atau membeli barang yang dijual toko tersebut. Suasana toko mencakup keseluruhan dari toko tersebut, baik itu dari dalam toko ataupun dari luar toko. Keadaan di luar dan di dalam toko dapat mencerminkan bagaimana toko tersebut. Pengusaha toko kelontong berusaha untuk membuat konsep toko senyaman mungkin. Akan tetapi seiring berjalannya waktu, tidak menutup kemungkinan ada beberapa hal yang dapat membuat suasana toko tidak benarbenar berjalan seperti saat pertama kali dibuka.

Sebagai contohnya peranan pegawai toko yang tidak terlalu sigap dalam melayani konsumen yang datang. Bila tidak segera diperbaiki, maka tidak menutup kemungkinan konsumen pun akan beralih ke toko pesaing. Dengan kata lain, saat ini suasana toko menjadi faktor yang penting dalam menentukan kelangsungan sebuah bisnis yang dijalankan. Oleh karena itu, saat ini para pelaku bisnis berlombalomba untuk menunjukkan kreativitasnya melalui bentuk-bentuk suasana toko yang mencoba berbeda dari yang 
lainnya. Semua hal ini dilakukan agar tokonya kelihatan menarik, dan diharapkan akan dapat meningkatkan minat konsumen untuk menggunakan produknya, serta dapat bersaing dengan pelaku bisnis yang sejenis. Selain suasana toko yang ditawarkan, penetapan harga juga dapat menjadi faktor lainnya yang dapat membantu kelangsungan dari sebuah usaha.

Penetapan harga yang ditawarkan produsen secara tidak langsung dapat melihat kalangan mana yang akan dipilih produsen atas produknya. Penetapan harga tidak bisa dengan asal-asalan, atau semaunya produsen, itu semua dikarenakan bila penetapan harga tidak sesuai dengan apa yang konsumen harapkan dari produk yang mereka beli, tidak menutup kemungkinan produk tersebut akan ditinggalkan.

Oleh karena itu dalam menetapkan sebuah harga para produsen harus benar-benar sesuai dengan produk apa yang akan mereka jual. Kesesuaian harga menentukan sejauh mana produk yang dijual diterima oleh konsumen dan dirasa sesuai dengan apa yang konsumen harapkan dari produk yang ditawarkan. Toko kelontong selalu menentukan dan memilih harga yang relatif murah agar dapat bersaing. Dengan demikian, konsumen yang datang dan membeli akan semakin banyak. Tujuan utamanya adalah agar bisa bersaing dan bisnis yang dijalankan bisa terus bertahan bahkan berkembang dengan membuka toko baru sebagai perluasan dari usaha mereka ataupun memperluas toko kelontong mereka.

Harga dari sebuah produk atau jasa sangat diperhitungkan oleh sebagian besar konsumen, karena konsumen tidak mau dirugikan dengan apa yang telah mereka keluarkan. Dengan demikian, harga menjadi salah satu faktor penting yang harus dipikirkan oleh pihak produsen, dikarenakan kesesuaian harga dengan produk yang dijual akan sangat mempengaruhi penjualan yang dilakukan. Bila harga sesuai dengan produk yang dijual, maka secara tidak langsung konsumen akan merasa puas dan menggunakan produk yang dijual tersebut. Begitu pula sebaliknya, jika harga dirasakan tidak sesuai oleh konsumen, maka produk yang dijual akan ditinggalkan. Dengan demikian, semakin banyak pelaku bisnis yang serupa, maka para pelaku bisnis harus memperhatikan segala faktor yang dapat mempengaruhi bisnis yang dijalankan, terutama untuk menarik minat pembeli. Cara menarik minat pembeli bisa dilakukan dengan segala cara dan alat pendukung yang beraneka ragam.

\section{METODE PENELITIAN}

Jenis penelitian yang digunakan pada penelitian ini adalah penelitian kualitatif. Menurut Sugiyono (2014: 347) penelitian kualitatif berarti proses eksplorasi dan memahami makna perilaku individu dan kelompok, menggambarkan masalah sosial atau masalah kemanusiaan. Proses penelitian mencakup membuat pertanyaan penelitian dan prosedur yang masih bersifat sementara, mengumpulkan data pada setting partisipan, analisis data secara induktif, membangun data yang parsial ke dalam tema, dan selanjutnya memberikan interpretasi terhadap makna suatu data. Kegiatan akhir adalah membuat laporan ke dalam struktur yang fleksibel. Metode penelitian yang digunakan dalam penelitian ini adalah metode penelitian kualitatif dengan pendekatan deskriptif, yaitu metode penelitian yang dilaku- 
kan untuk mengetahui kondisi alamiah obyek penelitian, di mana peneliti merupakan instrumen kunci, teknik pengumpulan data dilakukan secara triangulasi (gabungan), analisis data bersifat induktif/kualitatif, dan hasil penelitian kualitatif lebih menekankan ke makna dari pada generalisasi (Sugiyono, 2014: 347).

Dalam penelitian ini, objek yang akan diteliti adalah analisis minat beli pada toko kelontong di Kecamatan Wonokromo, Surabaya. Sedangkan subjek penelitian yang digunakan adalah adalah pemilik toko kelontong di Kecamatan Wonokromo, Surabaya. Metode pengumpulan data dalam penelitian ini adalah wawancara dan observasi. Wawancara adalah pertemuan kedua belah pihak antara orang yang memberikan pertanyaan serta orang yang menjawab dan saling bertukar informasi, sehingga dapat dibangun dalam suatu topik tertentu.

Metode wawancara yang digunakan adalah wawancara semi terstruktur, di mana peneliti sebelumnya sudah menyiapkan topik, daftar pertanyaan serta pemandu wawancara sebelum wawancara dilakukan oleh peneliti (Sugiyono, 2014: 231). Tujuan digunakannya wawancara semi terstruktur pada penelitian ini adalah untuk mendapatkan data yang lebih banyak, karena peneliti bisa mengembangkan pedoman wawancara sesuai permasalahan yang ditemukan. Sedangkan observasi adalah teknik pengumpulan data yang dilakukan untuk membandingkan data yang didapat melalui wawancara dengan keadaan aslinya (Sugiyono, 2014: 225). Teknik pengambilan sampel yang digunakan dalam penelitian ini adalah non probability sampling dengan teknik purposive sampling, yaitu teknik pe- ngambilan sampel sumber data dengan suatu pertimbangan tertentu (Sugiyono, 2014: 366). Adapun pertimbangan atau kriteria yang digunakan peneliti untuk memilih narasumber dalam penelitian adalah para pemilik masing-masing toko kelontong yang berjumlah 20 orang.

Validitas dalam penelitian kualitatif disebut autentisitas atau keaslian, yaitu jujur, adil, seimbang, dan sesuai berdasarkan sudut pandang individu atau subjek yang bersangkutan. Sedangkan reliabilitas dalam penelitian kualitatif adalah tingkat kesesuaian antara data atau uraian yang dikemukakan oleh subjek dengan kondisi sebenarnya (Hardiansyah, 2011: 81). Uji validitas yang digunakan dalam penelitian ini adalah triangulasi sumber, yaitu teknik yang digunakan untuk menguji kredibilitas data yang dilakukan dengan cara mengecek data yang telah diperoleh melalui beberapa sumber (Sugiyono, 2014: 440). Alasan digunakannya teknik triangulasi sumber, karena peneliti ingin mendapatkan pandangan atau pendapat dari sumber yang berbeda (pemilik toko kelontong, target konsumen, dan konsumen) mengenai masalah yang diteliti. Sugiyono (2014: 444) juga menjelaskan bahwa uji reliabilitas pada penelitian kualitatif dilakukan dengan pengujian dependability yang dilakukan melalui audit oleh peneliti terhadap konsistensi jawaban yang diberikan informan selama pengumpulan data.

Teknik analisis data yang digunakan oleh peneliti adalah teknik analisis data Miles dan Huberman (Sugiyono, 2014: 404) yang dilakukan pada saat pengumpulan data berlangsung dan setelah selesai pengumpulan data dalam periode tertentu. 


\section{PEMBAHASAN \\ Exterior}

Exterior yaitu bagian luar toko (bagian depan) yang mampu menggambarkan karakteristik toko. Design exterior yang memiliki ciri khas mampu membuat konsumen tertarik untuk masuk ke dalam toko. Toko kelontong di Kecamatan Wonokromo, Surabaya adalah toko kelontong yang memiliki exterior toko yang sederhana. Kelemahan pada exterior usaha toko kelontong adalah bahwa mereka yang menjalani usaha ritel ini adalah mereka yang tidak serius dalam berbisnis. Salah satu alasannya adalah karena bentuk usahanya yang kecil dan juga laba yang didapatkan dari satu produk terjual relatif kecil, sehingga hanya dianggap sebagai usaha sampingan. Padahal, jika ditotal dalam satu kurun waktu, laba yang didapatkan oleh usaha ritel cukup besar jumlahnya. Dengan keadaan demikian, toko kelontong di Kecamatan Wonokromo, Surabaya cenderung asal-asalan dalam menentukan tema exterior yang bisa menarik pelanggan untuk melakukan transaksi di toko kelontong mereka.

\section{General Interior}

Dari hasil wawancara yang dilakukan peneliti pada toko kelontong di Kecamatan Wonokromo, Surabaya, baik itu wawancara kepada pemilik toko kelontong ataupun pihak-pihak yang berhubungan dengan toko kelontong tersebut, maka data yang diperoleh adalah bahwa prinsip utama dari penjualan di toko kelontong adalah menyediakan barang kebutuhan konsumen yang selengkap-lengkapnya dengan peletakan barang yang seadanya. Ini dikarenakan ukuran toko kelontong di Kecamatan Wonokromo, Surabaya yang tergolong kecil, sehingga barang- barang diletakkan tanpa memperhatikan display yang bisa mengundang keinginan konsumen untuk tertarik membeli.

Penataan barang pada toko kelontong di Kecamatan Wonokromo, Surabaya dilakukan dengan sederhana juga dikarenakan konsumen toko ketika datang ke toko kelontong untuk membeli barang langsung menanyakan keberadaan barang yang menjadi kebutuhannya kepada pemilik toko ataupun pegawai toko yang ditunjuk oleh toko untuk mewakilinya.

\section{Store Layout}

Store layout merupakan rencana untuk menentukan lokasi tertentu dan pengaturan dari peralatan barang dagangan di dalam toko serta fasilitas toko antara pengaturan lalu lintas toko, pengelompokan barang, dan alokasi ruang. Dari wawancara yang peneliti lakukan kepada pemilik toko, diperoleh data bahwa layout toko untuk memperlancar lalu lintas barang yang dibutuhkan oleh konsumen dibuat dengan sederhana. Artinya bahwa layout yang mereka buat bukan consumer oriented melainkan pemanfaatan ruang yang ada dengan barang kebutuhan yang banyak. Kalau perlu ruangan toko dipenuhi barang-barang yang tidak perlu konsumen ketahui letaknya, tetapi ketika konsumen membutuhkan, maka pemilik toko kelontong atau pegawai yang mewakilinya dapat mengambilkannya. Ini menimbulkan kelambatan dalam pelayanan, karena sering kali disebabkan keterbatasan ruang mereka meletakkan barang dengan prinsip yang tidak sesuai dengan standar manajemen ritel, dan ketika konsumen mau membeli barang kebutuhan mereka, sering kali pemilik toko kelontong ataupun pegawai yang 
mewakilinya lupa tempat barang yang dibutuhkan tersebut.

\section{Interior Display}

Interior display bertujuan untuk memberikan informasi pada konsumen yang berbelanja, merupakan tambahan untuk memberikan kesan berbeda pada store atmosphere dan berfungsi sebagai alat promosi. Dari hasil wawancara peneliti, dalam menentukan interior display mereka tidak mengikuti standar yang baku, tetapi mengikuti kemampuan finansial toko kelontong yang mereka kelola. Mereka akan membuat interior display yang baik jika dapat promo dari supplier mereka. Jadi bukan dari inisiatif pengusaha toko kelontong. Ini terjadi karena keterbatasan dana yang dimiliki pada pengelolaan toko mereka. Jika ada keuntungan, pengusaha toko kelontong lebih memilih pemenuhan persediaan barang daripada harus investasi pada store atmosphere.

\section{SIMPULAN}

Toko kelontong di Kecamatan Wonokromo, Surabaya terdiri dari toko-toko kelontong sederhana yang menyediakan kebutuhan sehari-hari. Pada pendekatan store atmosphere untuk meningkatkan minat beli konsumen, toko kelontong di Kecamatan Wonokromo, Surabaya masih memiliki kelemahan yang disebabkan karena kekurangtahuan mereka akan standar ba$\mathrm{ku}$ tentang arti pentingnya store atmosphere bagi peningkatan pendapatan toko yang mereka kelola.

\section{SARAN}

Untuk dapat bersaing dengan toko-toko ritel modern yang sudah menerapkan store atmosphere untuk meningkatkan minat beli masyarakat gu- na berbelanja di toko mereka, maka toko kelontong di Kecamatan Wonokromo, Surabaya harus berbenah dan melakukan pendekatan store atmosphere agar minat beli masyarakat untuk berbelanja di toko kelontong mereka semakin lama semakin meningkat.

\section{DAFTAR KEPUSTAKAAN}

Amirulah, 2002, Perilaku Konsumen, Graha Illmu, Yogyakarta.

Berman, Barry and Joel R. Evans, 1992, Retail Management, Fifth Edition, Macmilan Publishing Company, USA.

Durianto, Darmadi dan Cicilia Liana, 2004, Strategi Menaklukkan Pasar Melalui Riset Ekuitas dan Perilaku Merek, PT Gramedia Pustaka Utama, Jakarta.

Fandi, Tjiptono, 2008, Strategi Pemasaran, Edisi Ketiga, Penerbit Andi, Yogyakarta.

Foster, Bob, 2008, Manajemen Ritel, Alfabeta, Bandung.

Hardiansyah, 2011, Kualitas Pelayanan Publik, Gava Media, Yogyakarta.

Kotler, Philip, 1973, Atmospherics as A Marketing Tool, Journal of Retailing, Vol. 49, No. 4, page 48-64.

Kotler, Philip dan Kevin Lane Keller, 2019, Manajemen Pemasaran, Jilid Satu, Edisi ke-13, Erlangga, Jakarta.

Levy, Michaeil and Barton Weitz, 2001, Retailing Management, International Edition, McGraw-Hill, New York. 
Sugiyono, 2014, Metode Penelitian Pendidikan: Pendekatan Kuantitatif, Kualitatif, dan R\&D. Alfabeta, Bandung.

Suyono, A. G., Sri Sukmawati, dan Pramono, 2012, Pertimbangan Dalam Membeli Produk Barang Maupun Jasa, Intidayu Press, Jakarta.
Yuliadi, 2006, Analisis Pengaruh Kualitas, Harga, Keunikan Produk dan Layanan Purna Jual Terhadap Minat Beli Konsumen Motorsport (Studi Kasus Pada Masyarakat di Kota Pati). 